\title{
ANTIMUTAGENIC EFFECTS OF ETHANOL EXTRACT OF SYZYGIUM MYRTIFOLIUM WALP. IN CYCLOPHOSPHAMIDE-INDUCED MICE
}

\author{
IRENE SONDANG LINGGA, URIP HARAHAP*, YUANDANI
}

Department of Pharmacology, Faculty of Pharmacy, Universitas Sumatera Utara, Medan, Indonesia. *Email: urip@usu.ac.id

Received: 19 December 2017, Revised and Accepted: 26 January 2018

\section{ABSTRACT}

Objective: This current study was carried to evaluate the antimutagenic effects of ethanol extract Syzygium myrtifolium Walp. in cyclophosphamideinduced mice.

Methods: The mice were divided into 6 groups with the total number of 30 mice (CMC Na 0,5\%; cyclophosphamide 30 mg/kg bw; and extract 50,100 , 200 , and $400 \mathrm{mg} / \mathrm{kg} \mathrm{bw}$ ) consisting of 5 rats for each group. All mice were induced by cyclophosphamide $30 \mathrm{mg} / \mathrm{kg}$ bw on day 1 , then followed by administration of extract for 7 days. On day 8, the blood was collected to evaluate the hematocrit value, while the femoral bone marrow was collected to determine the number of micronucleus cells.

Results: The ethanol extracts of S. Myrtifolium leaves at doses of 50-400 mg/kg bw demonstrated antimutagenic effect by inhibiting the formation of micronucleus as compared to negative control (CMC Na 0.5\%). Meanwhile, the hematocrit value increased at dose of 100,200 , and $400 \mathrm{mg} / \mathrm{kg}$ bw as compared to negative control.

Conclusion: This finding suggests that ethanol extract of $S$. myrtifolium has antimutagenic activity that may increase the normal cell number in cyclophosphamide-induced mice.

Keywords: Pucuk merah, Syzygium myrtifolium Walp., Antimutagenic.

(C) 2018 The Authors. Published by Innovare Academic Sciences Pvt Ltd. This is an open access article under the CC BY license (http://creativecommons. org/licenses/by/4. 0/) DOI: http://dx.doi.org/10.22159/ajpcr.2018.v11i6.24350

\section{INTRODUCTION}

Free radicals are atomic or molecular compound that contains one or more unpaired electrons. Antioxidants are substances that inhibit the oxidation reactions of free radicals. Oxidation is a chemical reaction that transfers electrons from one substance to an oxidizer. Oxidation reactions can produce free radicals and lead to chain reactions that cause the cellular damage in the body [1].

Various studies were conducted to develop the traditional treatments sourced from herbs. The redbud or known as Pucuk merah (Syzygium myrtifolium Walp.) is a Myrtaceae family that widely used in traditional medicines. In a previous study by Santoni et al. [2], who examined the fruit of $S$. myrtifolium that contains anthocyanin content as an antioxidant. The green leaf of $S$. myrtifolium contains phenolic and flavonoid compounds with antiangiogenic [3], as anticancer of chalcone compound [4], and anticancer potential using BSLT method [5]. While other Syzygium families have anti-cancer effects that are methanol extract Syzygium samarangense (wax apple) demonstrated higher DNA damage as well as cell growth inhibition [6], In consideration to these studies, it is necessary to recognize an alternative treatment for cancer prevention originated from herbs with antioxidant properties. This study was conducted to examine the antimutagenic effects of $S$. myrtifolium by measuring the number of micronucleus in polychromatic erythrocytes (PCEs) and normochromatic erythrocytes (NCEs) in mice bone marrow cyclophosphamide-induced. Then, hematocrit level of blood was observed.

\section{MATERIALS AND METHODS}

\section{Materials}

Drugs and chemicals used in this study were Aquadest, ethanol 96\%, $\mathrm{NaCl}, \mathrm{CMC} \mathrm{Na}$, Giemsa, fetal bovine serum, and cyclophosphamide $\left(\right.$ Cyclovid ${ }^{\circledR}$ ).

\section{Preparation of extracts}

S. myrtifolium Walp. was collected from Tanjung Morawa, Deli Serdang District, Sumatera Utara Province, Indonesia. The herb identification is done at "Herbarium Bogoriense" center of biological research Lembaga Ilmu Pengetahuan Indonesia (LIPI). Cibinong Science Center, Jl. Raya Jakarta-Bogor KM. 46 Cibinong 16911. The herbs were washed and dried at $30-35^{\circ} \mathrm{C}$, then grind until dried powder was obtained. The dried powder was macerated used ethanol $96 \%$, then the obtained macerate was evaporated and freeze-dried [7].

Animals

Animals used were healthy male mice weighing 25-30 g in suitable cages, given appropriate food and drink, acclimatized for 2 weeks before being treated. The animal experiment was approved by the Ethics Committee of the Institute No. 529/KEPH-FMIPA/2017

\section{Preparation animal experiments}

Animal tests used were 30 male mice weighed 20-30 g. Before treatment, the animals were acclimated for 2 weeks in a cage with good environment and adjusted the uniformity of food.

\section{Antimutagenic evaluation}

The antimutagenic evaluation applied to 30 mice that divided into 6 groups that consist of one normal group. Except normal group, mice were induced by cyclophosphamide $30 \mathrm{mg} / \mathrm{kg}$ bw intraperitoneally for $30 \mathrm{~h}$. The ethanol extract of $S$. myrtifolium 50,100,200, and $400 \mathrm{mg} / \mathrm{kg}$ was administered orally for 7 days. On day 8, the blood was collected for the determination of hematocrit level and femoral bones were collected values for micronucleus examination.

\section{Micronucleus calculation}

The emersive oil with 10 river microscope magnification was done to calculate 200 cells per mice. The NCEs and polychromatic erythrocytes with micronucleus (MnPCE) values were calculated. The toxic effects 
on bone marrow cells were evaluated by the ratio of PCE/PCE+NCE per 200 PCE cells [8].

\section{Hematocrit value determination}

The blood sample was collected from venous blood and added with anticoagulant of $3.8 \% \mathrm{Na}$ citric. The test was performed $<2 \mathrm{~h}$ after sampling. Blood samples were inserted into the capillary tube up to $2 / 3$ of the tube volume. One end of the pipe was closed. The sample was left manually upright $<2 \mathrm{~h}$ after sampling. Then, the height of the erythrocyte column was measured and compared with the height of the blood fluid. The value was expressed in percentage (\%) [9].

\section{Data analysis}

Data analysis was done using SPSS 17 followed by post hoc Tukey HSD test to obtain the difference between treatment groups $(\mathrm{p}<0.05)$

\section{RESULT}

The ethanol extract of S. myrtifolium leaf reduced the formation of micronucleus which was induced by cyclophosphamide and indicated as MNPCE. The toxicity of cyclophosphamide was attributed to the generation of free radical during its metabolism by cytochrome. Cyclophosphamide is an effective anticancer drug that belongs to the class of nitrogen mustards. The cytotoxic effect of CYP is directly connected with free radical-mediated metabolism. It is rapidly metabolized in the liver by cytochrome P-450 enzymes and generates active alkylating metabolites such as 4-hydroxycyclophosphamide, aldophosphamide, and acrolein, which interfere with cellular DNA synthesis in dividing cells and induce DNA single-strand breaks [10]. The variance analysis results are shown in Table 1.

The amount of micronucleus in the cyclophosphamide treatment group showed the significantly different results with the normal group. The activity of extract was in a dose-dependent manner. The average values of micronucleus in each treatment group are shown in Fig. 1.

Fig. 1 shows that the micronucleus values at a dose of $100 \mathrm{mg} / \mathrm{kg}$ of 22.2 \pm 1.15 did not different from the normal control group (CMC $\mathrm{Na}$ ) of $19.8 \pm 3.96$. Fig. 4.3 shows the micronucleus ratio resulted with PCE/PCE+NCE in each treatment group [8].

Micronucleus evaluation showed that ethanol extract of S. myrtifolium extract leaf has potential as antimutagenic. This was reinforced by more circulating blood red cells (erythrocytes) in the circulatory system. The higher hematocrit values were increased after treatment with ethanol extract of S. myrtifolium extract as shown in Table 2.

The increase of hematocrit values in the negative control resulted in the significantly different to the normal group and the treatment group of ethanol extract. Fig. 2 . shows the hematocrit average in each treatment group.

Theoretically, the carcinogenesis/mutagenesis may be prevented on initiation or promotion phase until the progression phase of inhibition. The initiation process can be inhibited by compounds that decrease the activation of metabolism of carcinogen compounds or prevent the occurrence of bonds between carcinogens and cellular targets [11].

\section{DISCUSSION}

Table 1 shows that the average values of micronuclear cells formed on CMC Na administration and extract of 50,100, 200, and with dosage $400 \mathrm{mg} / \mathrm{kg}$ were $19.8,51.0,22.2,20.8$, and 19.0 , respectively These were less than the average number of micronucleus formed in the negative group which induced by a cyclophosphamide solution (53.6). The negative effects of free radicals can exacerbate the damage of epithelial cells in the kidney tubules that play a role in the production of the hormone erythropoietin.

The micronucleus in young erythrocytes arises mainly from chromosomal fragments that are not incorporated into the daughter nuclei at the time
Table 1: MnPCE and PCE/PCE+NCE ratio

\begin{tabular}{|c|c|c|c|}
\hline No. & Group treatment & $\begin{array}{l}\text { MNPCE } / 200 \\
\text { cell } \pm \text { SEM }\end{array}$ & $\begin{array}{l}\text { PCE/ } \\
\text { PCE }+ \text { NCE } \pm \text { SEM }\end{array}$ \\
\hline 1 & CMC Na $0.5 \%$ & $19.8 \pm 2.13$ & $0.48 \pm 0.015$ \\
\hline 2 & $\begin{array}{l}\text { CMC } 0.5 \%+\text { cyclophosphamide } \\
(30 \mathrm{mg} / \mathrm{kg})\end{array}$ & $53.6 \pm 1.51$ & $0.42 \pm 0.007$ \\
\hline 3 & $\begin{array}{l}\text { S. myrtifolium extract } 50 \mathrm{mg} / \\
\mathrm{kg} \mathrm{bw}+\text { cyclophosphamide } \\
(30 \mathrm{mg} / \mathrm{kg})\end{array}$ & $51.0 \pm 2.91$ & $0.43 \pm 0.005$ \\
\hline 4 & $\begin{array}{l}\text { S. myrtifolium extract } 100 \\
\mathrm{mg} / \mathrm{kg} \text { bw+cyclophosphamide } \\
(30 \mathrm{mg} / \mathrm{kg})\end{array}$ & $22.2 \pm 1.15$ & $0.43 \pm 0.02$ \\
\hline 5 & $\begin{array}{l}\text { S. myrtifolium extract } 200 \\
\mathrm{mg} / \mathrm{kg} \mathrm{bw}+\text { cyclophosphamide } \\
(30 \mathrm{mg} / \mathrm{kg})\end{array}$ & $20.8 \pm 1.65$ & $0.45 \pm 0.013$ \\
\hline 6 & $\begin{array}{l}\text { S. myrtifolium extract } 400 \\
\mathrm{mg} / \mathrm{kg} \mathrm{bw}+\text { cyclophosphamide } \\
(30 \mathrm{mg} / \mathrm{kg} \text { ) }\end{array}$ & $19.0 \pm 0.44$ & $0.44 \pm 0.04$ \\
\hline
\end{tabular}

*The number in the Sig column. (a) $P<0.05$ there was a significant difference with the negative control (cyclophosphamide [Cyclovid]). (b) $P<0.05$ there was a significant difference with normal control (CMC Na). CMC Na: Carboxymethylcellulose natrium. SEM: Standard error mean. S. myrtifolium: Syzygium myrtifolium, PCE: Polychromatic erythrocytes, NCE: Normochromatic erythrocytes, MnPCE: Polychromatic erythrocytes with micronucleus

Table 2: The effect of $S$. myrtifolium extract on hematocrit value of cyclophosphamide-induced mice

\begin{tabular}{|c|c|c|}
\hline No. & Groups & $\%$ Hematocrit \pm SEM \\
\hline 1 & CMC Na $0.5 \%$ & $79.206 \pm 5.279$ \\
\hline 2 & $\begin{array}{l}\text { CMC Na 0.5\%+cyclophosphamide } \\
(30 \mathrm{mg} / \mathrm{kg})\end{array}$ & $67.356 \pm 5.146$ \\
\hline 3 & $\begin{array}{l}\text { S. myrtifolium extract } 50 \mathrm{mg} / \mathrm{kg} \\
\text { bw+cyclophosphamide } \\
(30 \mathrm{mg} / \mathrm{kg})\end{array}$ & $67.830 \pm 2.346$ \\
\hline 4 & $\begin{array}{l}\text { S. myrtifolium extract } 100 \mathrm{mg} / \mathrm{kg} \\
\text { bw+cyclophosphamide }(30 \mathrm{mg} / \mathrm{kg})\end{array}$ & $69.894 \pm 2.691$ \\
\hline 5 & $\begin{array}{l}\text { S. myrtifolium extract } 200 \mathrm{mg} / \mathrm{kg} \\
\text { bw+cyclophosphamide }(30 \mathrm{mg} / \mathrm{kg})\end{array}$ & $79.764 \pm 2.935$ \\
\hline 6 & $\begin{array}{l}\text { S. myrtifolium extract } 400 \mathrm{mg} / \mathrm{kg} \\
\text { bw+cyclophosphamide }(30 \mathrm{mg} / \mathrm{kg})\end{array}$ & $83.328 \pm 1.806$ \\
\hline
\end{tabular}

*The number in the Sig column. (a) $P<0.05$ there was a significant difference with negative control (cyclophosphamide [Cyclovid]). (b) $P<0.05$ there was a significant difference with normal control (CMC Na). CMC Na: Carboxymethylcellulose natrium, SEM: Standard error mean.

S. myrtifolium: Syzygium myrtifolium

of cell division in the erythropoietic blast cells. Immature cells called as polychromatic erythrocyte stains bluish due to the high content of RNA and mature cells called as normochromatic erythrocytes stains pink [12].

The erythropoietin hormone regulates the process of erythropoiesis in the bone marrow. This hormone increases the number of progenitor cells bound to erythropoiesis. Thus, the process of hematopoiesis is not impaired [13]. Stress erythropoiesis in the spleen is a common compensatory mechanism activated by tissue hypoxia produced during hemolysis. Persistent stress erythropoiesis indicates the defect in the management of tissue hypoxia due to hemolysis [14]

Flavonoids and its metabolites can modulate cells through action on protein kinase and lipid signaling of kinase pathways. The inhibition or stimulation of flavonoids on this pathway greatly influences the cell function by altering the phosphorylation of target molecules and modulating gene expression [15].

The antimutagenic effect expressed by inhibition of micronucleus formation and hematocrit values increasing is suspected to be 


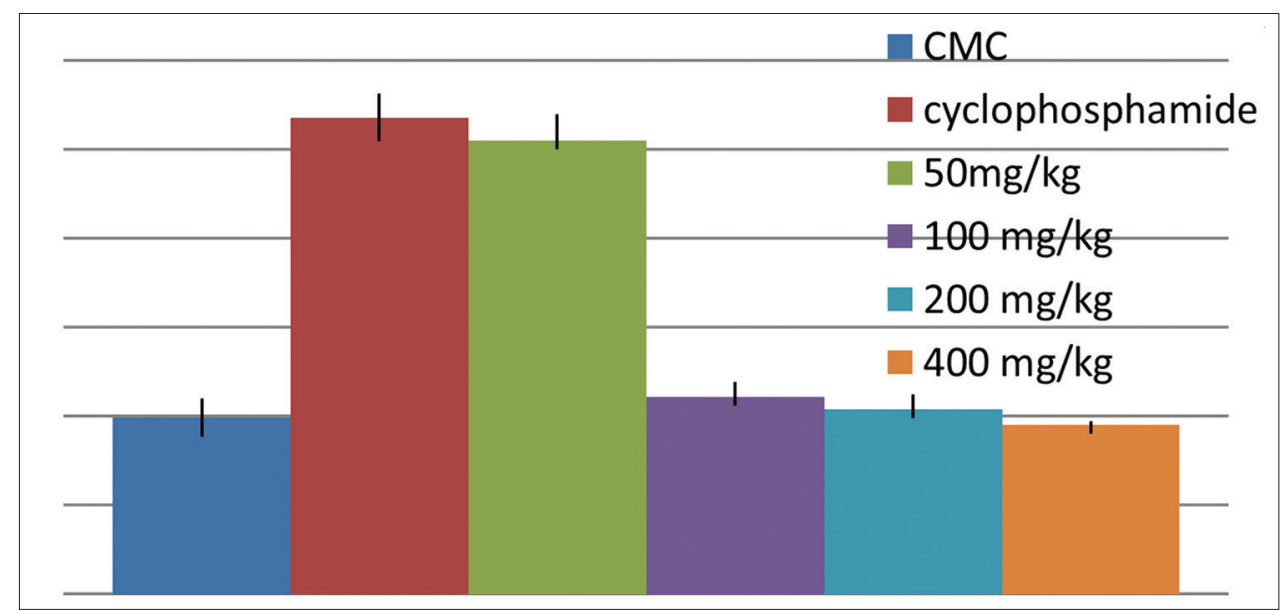

Fig. 1: The effect of Syzygium myrtifolium extract on micronucleus cells (polychromatic erythrocytes with micronucleus)

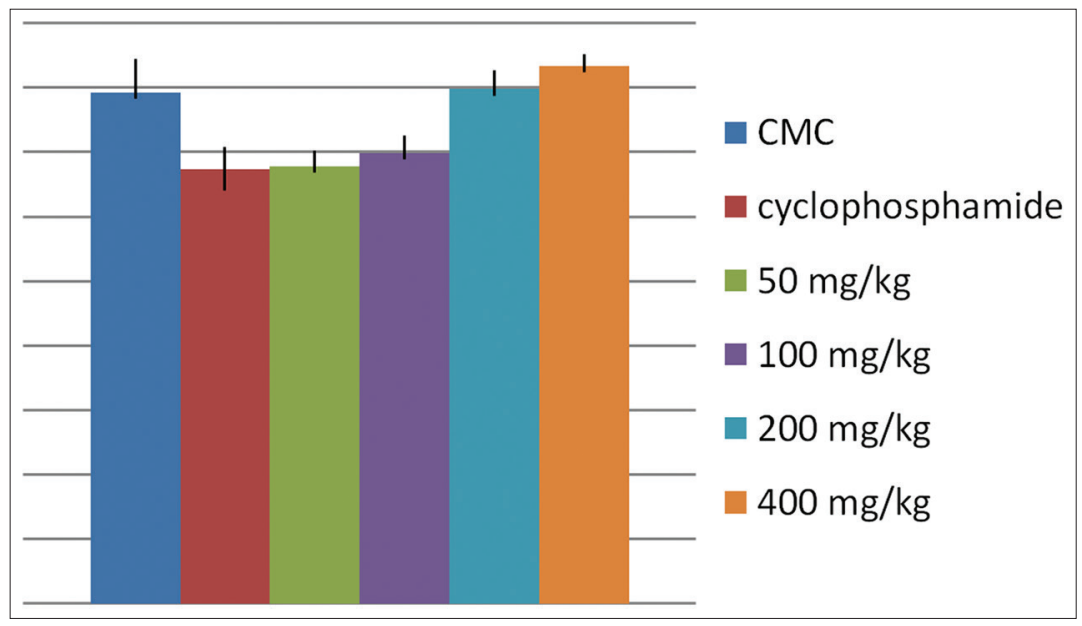

Fig. 2: The effect of Syzygium myrtifolium extract on Hematocrit value of cyclophosphamide-induced mice

associated with the presence of flavonoid compounds contained in ethanol extract of S. myrtifolium. Flavonoids are a secondary metabolite that potent as an antioxidant that may reduce the free radicals activity and antimutagenic potentialin it may play an important role in neutralization of various dietarymutagens and may act as a prophylactic agent against human ill-healthattributable to mutation [16].

Table 2 shows the low hematocrit value on the treatment of $50 \mathrm{mg} / \mathrm{kg}$ due to the hemolysis caused by the fragility of erythrocyte cell membrane and the presence of free radicals interact with oxygen to form peroxide radicals resulting in weak or brittle membranes [13]. This can be particularly due to the contribution of extracellular hemoglobin (EcHb) formed due to hemolysis, which is devoid of its antioxidant protectants that are normally available within the erythrocytes and can cause oxidative devastation in the vasculature [17]. Usually, a protective physiology will be initiated after hemolysis with the help of specialized plasma scavenger proteins to neutralize and eliminate this $\mathrm{EcHb}$. However, when this protective mechanism is overwhelmed by the high degree of hemolysis, EcHb remains in circulation and promotes inflammatory reactions [18].

\section{CONCLUSION}

The ethanol extract of $S$. myrtifolium leaf has antimutagenic activity, indicated by a decrease in the number of micronucleus in the bone marrow of the femur, and is able to increase the amount of erythrocytes of cyclophosphamide-induced mice at a dose of 100,200, and $400 \mathrm{mg} / \mathrm{kg}$ bw.

\section{REFERENCES}

1. Elfita M, Hotdelina S. Antioxidant activity and stability blend color mixture of ethyl acetate extract of Mangosteen fruit (Garcinia mangostana L.) and secang wood (Caesalpinia sappan L.). Evid Based Sains Univ Sriwijaya Sumatera Selatan 2012;15:61-9.

2. Santoni A, Darwis D, Syahri S. Isolation of Antosianin from Red Shoot (Syzygium campanulatum Korth.) as well as Antosianin Testing and Applications as Natural Dyes. Lampung: Prosiding Semirata Unila; 2013. p. $1-10$.

3. Aisha AF, Ismail Z, Abu-Salah KM, Siddiqui JM, Ghafar G, Abdul Majid AM, et al. Syzygium campanulatum korth methanolic extract inhibits angiogenesis and tumor growth in nude mice. BMC Complement Altern Med 2013;13:168.

4. Memon AH, Ismail Z, Aisha AF, Al-Suede FS, Hamil MS, Hashim S, et al. Isolation, characterization, crystal structure elucidation, and anticancer study of dimethyl cardamonin, isolated from Syzygium campanulatum korth. Evid Based Complement Alternat Med 2014;2014:470179.

5. Zulfikar E, Wiendarlina IY, Wardatun S. Search for Potential Anticancer of Red Shoot Leaf (Syzygium campanulatum Korth) by Method Brine Shrimps Lethality Test (BSLT). Bogor: University Pakuan; 2015.

6. Thampi NJ, Shalini V. Anti-proliferative and apoptotic activities of Syzygium samarangense (wax apple) fruits extract against human a549 lung cancer cell lines. Int J Pharm Pharm Sci 2015;7:361-5.

7. Ditjen PO. Farmakope Indonesia. $4^{\text {th }}$ ed. Jakarta: Departemen Kesehatan Republik Indonesia; 1995. p. 969-71, 1033.

8. Salmani A, Kosari AA, Pirouzi A, Omidi M, Mohsenzadeh M. Protective effect of methanolic extracts of Thymus vulgaris L. against cyclophosphamide-induced DNA damage in mouse bone marrow cells using the micronucleus test. Trends Pharm Sci 2015;1:243-50. 
9. Riswanto. Hematocrit Laboratory Examination. Yogyakarta: Alfa Media; 2013.

10. Matter B, Schmid W. Trenimon-induced chromosomal damage in bonemarrow cells of six mammalian species, evaluated by the micronucleus test. Mutat Res 1971;12:417-25.

11. Ruddon RW. Cancer Biology. $4^{\text {th }}$ ed. Michigsn: Oxford University Press Inc.; 2007. p. 62, 82, 92, 493.

12. Nagarathna PK, Yadav CK, Yadav SK. Evaluation of mutagenic effect (Antimutagenic) of dalbergia latifolia on swiss albino mice. Asian $\mathrm{J}$ Pharm Clin Res 2015;8:154-8.

13. Sjamsul A. Radikal bebas. Surabaya: The Child Health Sciences Division; 2008. p. 47-8.

14. Rajasekar GS, Brindha P, Ramanathan V. Effective management of hemolytic complications by traditionally prepared kāntam formulations.
Int J Pharm Pharm Sci 2017;9:27-34

15. Mansuri ML, Parihar P, Solanki I, Parihar MS. Flavonoids in modulation of cell survival signalling pathways. Genes Nutr 2014;9:400.

16. Radhakrishna M, Hedge MJ. Antimutagenic potential of LIV52 by ames salmonella/mammalian: Microsome mutagenicity assay. Asian J Pharm Clin Res 2017;10:277-82.

17. Dominik PW, Schaer J, Alayash AI, Belcher JD, Vercellotti GM. Hemolysis and free hemoglobinrevisited: Exploring haemoglobin and hemin scavengers as a novel class of therapeutic proteins. Blood 2013;121:1276-4.

18. Rifkind JM, Mohanty JG, Nagababu E. The pathophysiology of extracellular hemoglobin associated with enhanced oxidative reactions. Front Physiol 2014;5:500 